$$
\begin{aligned}
& \text { The submitted manuscript has been authored } \\
& \text { by a contractor of the U.S. Government } \\
& \text { under contract No. W-31-109-ENG-38. } \\
& \text { Accordingly, the U. S. Government retains a } \\
& \text { nonexciusive, royalty-free license to publish } \\
& \text { or reproduce the published form of this } \\
& \text { contribution, or allow others to do so, for } \\
& U \text {.S. Government purposes. }
\end{aligned}
$$

\title{
HOW SIGNIFICANT IS PERCEIVED ENVIRONMENTAL RISK TO BUSINESS LOCATION DECISIONS?
}

\author{
Tim Allison \\ Decision and Information Sciences Division \\ Argonne National Laboratory \\ Argonne, IL 60439-4832

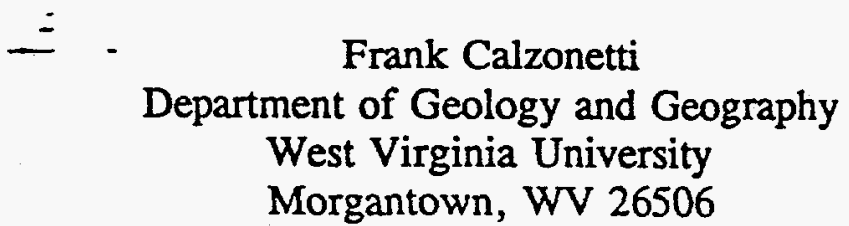

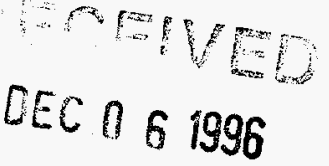

OSTI

Abstract

It has been argued that adverse perceptions of risk associated with high-level nuclear waste (HLNW) facilities will have significant impacts on the attraction of new, and the maintenance of existing business activities in areas in which adverse perceptions develop. We examine this proposition by the considering the importance of environmental amenities and a range of other factors to business location decisions using evidence from surveys of more than 400 manufacturing and business service establishments in Colorado and Utah. We show that the importance of environmental amenities varies according to a number of factors, in particular the type of product (manufactured product or business service), type of establishment (single-establishment firm or establishment of a multilocational firm) and establishment employment size. Policies designed to offset the loss of business activity that might result from adverse risk perceptions associated with HLNW facilities must therefore take into account how sensitive various forms of business activity present or likely to locate in any particular area might be to environmental factors.

Keywords: Perceived risk; amenities, disamenities; business location factors.

\section{Introduction}

Evaluation of the significance of perception-based impacts associated with nuclear facilities has become an increasingly important part of socioeconomic impact assessment in recent years. Much of this work has been undertaken in response to the development of the U.S. Department of Energy's Yucca Mountain high-level nuclear waste (HLNW) repository project in southern Nevada. The evaluation of the impact of risk perceptions has also formed a part of the assessment of the economic impacts of planned temporary nuclear waste storage facilities. Not suprisingly, given the significance of the siting and public acceptance of high- 


\section{DISCLAIMER}

Portions of this document may be illegible in electronic image products. Images are produced from the best available original document. 


\section{DISCLAIMER}

This report was prepared as an account of work sponsored by an agency of the United States Government. Neither the United States Government nor any agency thereof, nor any of their employees, make any warranty, express or implied, or assumes any legal liability or responsibility for the accuracy, completeness, or usefulness of any information, apparatus, product, or process disclosed, or represents that its use would not infringe privately owned rights. Reference herein to any specific commercial product, process, or service by trade name, trademark, manufacturer, or otherwise does not necessarily constitute or imply its endorsement, recommendation, or favoring by the United States Government or any agency thereof. The views and opinions of authors expressed herein do not necessarily state or reflect those of the United States Government or any agency thereof. 
level nuclear waste projects to national energy and environmental policy, the issue has also received much attention in the press (see Erikson 1994, for example). Attempts to develop a predictive framework to directly assess the type and precise magnitude of economic impacts of nuclear waste facilities, however, are somewhat rudimentary and have not been widely accepted (see Slovic et al. 1991; Bassett and Hemphill 1991).

Information on the economic impact of risk perceptions associated with the repository project uses data taken from public opinion surveys to suggest that adverse perceptions of risk will lead to a decline in retirement and in-migration to southern Nevada (Kunreuther et al. 1988; Slovic et al. 1989; 1991), tourism and conference visits (Kunreuther et al. 1988; Easterling and Kunreuther 1990), will affect decisions made by individuals to invest in the area (Mushkatel et at: 1990), and adversely effect decisions made to locate new and maintain existing businesses in the area (Center for Survey Research 1988; Decision Research and Mountain West 1989; Slovic et al. 1989; 1991). Additional research on the economic development potential of southern Nevada, in particular the image of Las Vegas as a potential business location, has also been used to suggest that adverse risk perceptions associated with HLNW will have significant impacts on new business growth in the area (Growth Strategies Organization 1988a, 1988b). Work elsewhere on the impacts of risk perceptions associated with temporary nuclear waste storage facilities examines perceptions held by local business executives in Tennessee, also using information taken from surveys (Fox et al. 1985).

In the work which examines the impacts of HLNW in both southern Nevada and Tennessee, the assessment of impacts of risk perceptions on business location decisions is included with the assessment of impacts on aspects of economic behavior that may be based entirely on individual personal preferences (decisions to attend conferences, family visits, tourism, retirement, etc.). Decisions to maintain or locate business activities, however, are unlikely to be based on the same personal decisionmaking framework. There are two reasons for this. The first is that there are a variety of economic constraints that determine the basis for choosing a location, in particular the cost of access to the necessary labor and product markets, location specific costs of doing business, etc., in addition to environmental considerations. For many business activities, environmental considerations are likely to be introduced into the decision to locate business activity only after the various economic constraints have been satisfied. The second is that many manufacturing and business service activities in a location are branch establishments of larger multilocational business organizations. These organizations tend to locate branch establishments for relatively specialized activities where only a small number of location factors, in particular local labor markets, are important in the location decision. As branch establishments are controlled externally from headquarters facilities or other company facilities at locations elsewhere, the role of the personal preferences of location decisionmakers are likely to have a minimal impact on the choice of location for branch establishments.

In this paper, we bring new information to the debate on the link between risk perceptions and economic development through an evaluation of the relationship between 
environmental amenities and the location of different types of business activity. The paper uses information gathered from surveys of business executives in a range of different manufacturing and service activities. We argue that while adverse risk perceptions associated with HLNW facilities may translate into how locations are rated as places to do business, business location decisions are also influenced by a series of factors in addition to environmental considerations in particular locations. We consider the significance of perceived risk indirectly by examining the significance of amenities and disamenities (broadly defined to include natural, cultural and recreational features, environmental quality and other indices of quality of life) on business location decisions, compared to a other factors typically considered by business executives. We direct our argument and findings specifically at the debate over the potential impacts of perceived risk on the nature of business location decisions in areas likeity to be impacted by HLNW storage and disposal programs, in particular southern Nevada, but also to rural locations that may host interim Monitored Retrievable Storage (MRS) facilities.

The importance of amenities and disamenities is compared to a wide range of other factors known to influence both initial choice of location, and the continued operation of business activities in existing locations. We examine the location preferences of two broad type of business activities, manufacturing and business services, and examine the role of establishment size (number of employees). Also considered is the role of type of establishment (single establishment firm or establishment of multilocational firm) on how each location factor is rated by each respondent. It is likely that establishments in these two broad groupings will have different occupational structures. Single establishment firm tend to support a wide range of high order executive and managerial occupations, in addition to lower order administrative and production occupations, while establishment of multilocational firms tend to be more specialized in lower order administrative and production occupations. This difference is likely to play an important role in how amenities and disamenities are rated, with higher order occupational groups more likely to influence location decisions.

The majority of industrial location surveys consider factors that were important to a firm in choosing the present location for the establishment. Our survey differs by examining locational factors that are currently considered important by individual business activities in the decision to choose another location or remain in their present locations. We are able therefore measure the factors that might contribute to 'locational stress' associated with existing locations, and those factors most likely to be associated with choosing another, more preferable location. Information is taken from telephone surveys of owners and managers of business activities in Colorado and Utah. These states were chosen in an attempt to replicate many of the economic and environmental conditions that may be considered to be important location factors by existing and potential new businesses in Nevada. Both states have many of the cultural, recreational, physical and environmental amenities that may be found in Nevada that are attractive to business executives and key personnel. Both states compete with Nevada as sites for firms considering locations for new or expanded establishments in the mountain states. In addition, both states have diverse economic bases and are made up of cities and communities with a wide range of size categories, meaning that the survey data 
collected in these states provides findings that can be used to reasonably predict locational behavior in southern Nevada and elsewhere.

The paper is in five sections. Section 2 discusses work completed to date on the potential impact of adverse risk perceptions on business location behavior, both in southern Nevada and elsewhere. Section 3 summarizes findings in the academic literature on the importance of amenities to business location decisions, with particular regard to the role of establishment size, type and product type. Section 4 outlines the design of the survey of manufacturing and producer service establishments in Colorado and Utah, and outlines the characteristics of responding establishments. Section 5 describes the results of the surveys, providing information on the significance of amenities and disamenities to manufacturing and business service estabishments and comparing amenities with other factors that influence location decisions. The significance of amenities and disamenities is describes according to size of the establishment and type of establishment (single-location establishment or branch establishment of a multilocational firm) and product type. Section 6 summarizes the findings of the empirical work and Section 7 discusses the implications of the survey results on the impact of risk perceptions associated with high-level waste facilities. We discuss the nature of potential impacts both for Las Vegas and for other metropolitan locations, and for rural locations that might become host to temporary Monitored Retreivable Storage (MRS) facilities.

\section{Risk Perceptions and Business Location Decisions}

Although the impacts of risk perceptions on business location decisions has received attention in the press with respect to various nuclear activities and facilities, very little academic research considers the impact of risk perceptions associated with HLNW facilities on business location decisions. The work which has been completed to date has focused primarily on evaluation of the potential impact of the Yucca Mountain facility in southern Nevada, used survey information gathered from business executives to predict impacts on business location decisions. Other work, which considers the economic impact of an MRS facility in Tennessee, also used survey information gathered from business executives.

The first of the surveys that considers the impact of risk perceptions in southern Nevada used a sample of U.S. households and asked respondents to state their perceptions of Las Vegas as a place to live, work, raise a family, retire, visit, attend a conference, or locate a business, both before and after the repository (Center for Survey Research 1988). The results showed that Las Vegas was viewed as a desirable place to visit or attend a convention but less desirable as a place to raise a family, locate a business, or retire without the repository. The average desirability rating declined by $13 \%$ across all questions after the repository was introduced into each interview, with changes in the desirability rating apparently related to the length of stay implied in each activity (convention, visit etc.). When asked whether they would visit Las Vegas after the repository had been built, $34 \%$ of the respondents changed their rating (from desirable to undesirable), but when asked about 
the desirability of the city as a place to locate a business, 57\% changed their rating.

The second survey used a sample of corporate executives and asked interviewees to describe six images they had of Albuquerque, Denver, Las Vegas, and Phoenix (Decision Research and Mountain West 1989). Each respondent rated images on a five-point scale ranging from very positive to very negative, with the sum of the ratings for all the images from each respondent used to specify images associated with each city. For Las Vegas, 23 images associated with the physical and business environment were identified, with images that associated the city with nuclear facilities appearing twice. Respondents were also asked to rank five business location factors (work force availability, image of the city, availability and cost of space, quality of life, and accessibility to markets) and to list places they had considered as new leeations in the past. Interviewees were also asked to consider if and how proximity to various undesirable facilities and environmental conditions (ambient air quality, floodplain location, and likelihood of earthquake tremors) would affect their location decision in a particular community, with ratings collected for a series of waste and manufacturing facilities.

Scores from the city ranking exercise were compared with the scores generated by the imagery tests. It was hypothesized that respondents' preferences for places in which to locate business facilities would be predictable from the images of the four cities. The results showed that preferences matched images in $47 \%$ of the cases involving the first choice for a business location, $32 \%$ for the second choice, and $34 \%$ for the third. Linear relationships were then estimated from image difference scores by pairing each of the four cities with every other city to produce six pairs (A-B, A-C, A-D, B-C, B-D, and C-D), subtracting the image score of one city from the image score of one other city for all pairs, ordering the resulting scores, and dividing them into subsets. Within each subset, the percentage of respondents preferring one city to another city as a business location was calculated. Results of the image difference tests appeared to show that business location preferences are fairly predictable. In logit form, the models produced highly linear results with relatively steep curves, suggesting that changes in only one or two of the images could lead to large shifts in the preferences for business location factors.

The survey of business executives in Tennessee asked a sample of local businessmen how they thought local businesses would respond to the location of an MRS facility in the state (Fox et al. 1985). The majority of respondents thought attracting new and maintaining existing businesses and attracting workers would be difficult, although respondents reacted more favorably if the MRS facility were associated with changes in local property tax rates. The survey also found that responses were different across industry groups, with financial services activities least likely to locate near the facility, compared to manufacturing and retail activities.

On the basis of the limited evidence from southern Nevada, the conclusion is drawn that risk perceptions associated with the repository project will have an impact on the attractiveness of the area to exisitng or new business establishments (Decision Research and 
Mountain West 1990). The survey of business executives in Tennessee draws similar conclusions. The studies on which this conclusion is based have a number of weaknesses. The first two weaknesses relate to the treatment of economic impacts in the work which assesses the importance on perceived risk. These weaknesses represent a substantial area still to be fully explored in the literature on perceived risk, rather than specifically to business location decisions, and we therefore only mention them in passing. The remaining criticism relates to the way in which business location decisions have been treated in the work on perceived risk. This will be the focus of the paper.

The first weaknesses of the work on southern Nevada and elsewhere is the assumption that stated perceptions of the risks individuals may associate with the repository will necessarily be translated into subsequent economic behavior. There has been much debate over the value of surveys such as these as an indicator of the nature of socioeconomic impacts from a particular policy or strategy. Often it may be difficult to show exactly how reactions by individuals to an intended course of action will be translated into future behavior with some associated high probability. This may be the case in particular in the case of stated preferences with respect to business location decisions, given that the majority of business activities have a range of non-amenity factors they must consider to remain competitive, and those that consider environmental factors may also face substantial inertia once a location to do business has been chosen. A second weakness is the assumption that if the translation from perceptions to economic behavior does occur, exactly what the type and magnitude of impacts are likely to be. Attempts to develop a predictive framework to directly assess the nature of subsequent, risk perception related behavior, however, have not been completely successful or widely accepted (see Slovic et al. 1991; Bassett and Hemphill 1991). Conclusions on the general nature of economic impacts of risk perceptions associated with nuclear waste facilities include impacts on business location decisions, but only one of the surveys deals with business location decisions specifically as a separate issue. Unfortunately, as there has been so little other work to date on the relationship between perceived risk and business location decisions with which to compare this work. The results of the work reviewed above would seem, however, to be overly reliant on the existence and significant magnitude of this relationship, and as a result seem likely to overstate the magnitude of impacts on business location decisions in the areas in which risk perceptions develop.

A third weakness of the Nevada and Tennessee surveys, and the focus of this paper, is that there is very little detailed information on the significance of perceived risk to business location decisions made by particular types of business activities in the surveys. As has been suggested and as we will show in the remainder of this paper, risk perceptions may not affect all business activities to the same degree. No attempt was made in the surveys to distinguish among the differential effects that risk perceptions may have on the type and level of business activity, in particular the type of product (manufactured product or business service), type of establishment (single-establishment firm or establishment of a multilocational firm) and establishment employment size. The significance of environmental amenities on decisions to locate a particular type or size of facility depends on the impact of 
amenities either on costs, or on the personal preferences of entrepreneurs or top-level corporate decision makers. Cost effects may be direct, relating to a firm's own cost function or the cost function of other firms that are also using the amenity, or they may be indirect, flowing from the use and degradation of environmental amenities that affect the nonamenity parts of a firm's cost function (e.g., the cost of maintaining certain occupational groups in a location).

The indirect effects of amenities on costs may be particularly important. Employees in scientific and technical occupations requiring a high level of training tend to be highly mobile and have been shown to choose locations on the basis of the local or regional provision of amenities. Many firms may be indirectly forced to factor the effects of the siting of hazardous facilities in their location decisions, if stigmatization and perception-based impacts lead to migration of essential parts of their labor force away from the affected areas. The impact of the indirect effect of amenities is likely to be closely related to the occupational structure of the firms in the affected area. This structure, in turn, is likely to be related to a number of factors, in particular the firm's product, technology, size, and organizational structure. Perception-based impacts may also affect location decisions through the impact of changes in amenity values and the personal preference for the region or locale in which to conduct business. Although many small businesses, particularly small manufacturers, do not have the resources to conduct a search of alternative locations or access to capital if a suitable alternative location can be identified, it is apparent that smaller producer service firms, particularly those run by highly educated individuals, may respond to changes in the level of amenities and perceived risk in a location. Again the importance of amenities to specific businesses and industrial activities needs to evaluated, with particular reference to a firm's product, technology, size, and organizational structure.

A additional weakness of the Nevada and Tennessee surveys is that they did not examine the attitudes of each individual toward economic development, which may have biased the results toward respondents that already had definite plans to expand or relocate in these areas. These respondents might have overstated their objections to the region as the host to nuclear facilities. In addition, although results of the surveys suggest that images of the Las Vegas and Tennessee can affect new business location preferences, the link between images and actual behavior may be tenuous. Although changes in images might lead to substantial shifts in preferences, they may not necessarily lead to similar changes in actual behavior.

\section{Environmental Amenities and Business Location Behavior}

Amenities have often been considered important to the attraction of industry by economic development officials and policymakers. Over the past thirty years regional and local amenity factors have commonly been promoted planners and local authorities as a means of attracting new industries (Smith 1971; Kale and Lonsdale 1979; Burgess 1982; Ballard and James 1983; Raitz 1988; Keeble 1989; Haider 1992; Gottlieb 1994). However, 
amenities have not been considered a major factor affecting business location decisions in the academic literature on business location decisions until recently. Academic research on how locations attract and retain industries has traditionally focused on the importance of the costs of labor, land, transportation, and other factors, such as local taxes and public services, that directly relate to the cost of opening or operating a business. Amenities are often treated as a residual personal factor in this work. More recent research has focused more specifically on amenities because of the growing importance of certain parts of the economy, particularly those activities that require highly educated labor force. Many of these activities are highly footloose in nature, not being limited to the relatively small number of locations where there are suitable raw materials, labor and product markets required in the more traditional manufacturing industries. For some industries, particularly high-tech manufacturing and business service activities; the location of highly educated labor may far outweigh the importance of other factors. These activities are often thought to respond indirectly to geographic differences in the level or type of amenities available through their reliance on highly educated labor located in amenity-rich areas.

A significant body of literature has developed that examines the role of amenities and disamenities to business location decisions. Work is based both on establishment-level data gathered from surveys, and county-level analysis using data from published sources. It is not the intention of this paper to review this literature in its entirety. Readers are instead referred to Greenwood 1981; Steinnes 1982; Wheat 1986; Carlino and Mills, 1987; Crown 1991; Kasarda and Irwin 1991 for the methodologies and findings of econometric studies (for a review, see Calzonetti and Hemphill 1990), and to McNulty (1986), Myers (1987), Malecki (1989), Calzonetti and Hemphill (1990), Allison (1991), Haider (1992) and Gottlieb (1994) for an overview of studies that have examined the importance of amenity factors to economic development. The purpose of this section is to review the work undertaken to date that specifically examines the importance of amenities by the type of product (manufactured product or business service), type of establishment (single-establishment firm or establishment of a multilocational firm) and establishment employment size.

Broad changes in the orientation of the U.S. economy toward light manufacturing and business services and of changes in the spatial organization of firms have placed a different emphasis on the factors that are important to the location of industries and has led to a growth in the importance of amenities and disamenities. In many cases, manufacturing and business service firms have become more flexible regarding the location of material inputs, and changes in transportation technology and telecommunications have reduced the costs of marketing many manufactured goods and business services. As a result, labor costs have often emerged as the single most important factor in determining the location of new industrial activities. Increased locational flexibility has allowed many firms, especially large corporations, to separate specific activities (such as headquarters, research and development facilities, support services, sales offices, and production facilities) and choose costminimizing locations for each activity on the basis of a consequently smaller number of minimum locational requirements. Accordingly, separate activities have developed their own locational patterns. 
Corporate headquarters and other high-level business services (e.g., finance, insurance, legal, advertising, and consulting services) have located in the centers of a small number of large cities. The economics of agglomeration dominate the location choices of headquarters and their associated service functions, particularly the need to minimize the costs of face-to-face contact between high-level executives. Nonetheless, part of the decision of where to locate headquarters facilities may be based on amenities found in metropolitan areas. For example, Schmenner (1982) surveyed several corporate headquarters in New England to establish which factors had been important in site selection. Schmenner found that when a choice was being made among regions, markets and labor (wages and labor skills) were most frequently ranked as important; amenities (aesthetic qualities) were important to only a small proportion of the respondents. However, when firms were required to choose specific sites for establishments at the local level, amenities were more important. Burns and Pang (1977) found that amenities were important to all 38 headquarters facilities that were surveyed in their decisions to relocate corporate headquarters from one central city location to another and from a central city location to a suburban location. In particular, cultural attractions, university facilities, entertainment, and residential environments were found to be important amenities. Firms involved in research and development also tend to be located at the peripheries of large urban centers, where the availability of scientific and technical labor and proximity to headquarters facilities are the most important location factors (Malecki 1989). Amenities are also important in the choice of locations for office activities in general, as distinct from corporate headquarters functions. Rhodes and Kan (1971), for example, conducted a survey of 60 commercial offices that had moved from central London, either partially or completely. The managers surveyed placed a high value on the quality of the area surrounding their new location, particularly its lack of a manufacturing base or the likelihood of one developing in the future. At the metropolitan level, access to recreational amenities has been considered a factor in the growth of office space and employment (Ihlanfeldt and Raper 1990).

Other establishments have been located in more peripheral areas and may not be influenced by locational amenities. The routine manufacturing branch establishments of larger corporations, for example, are often located on the basis of geographic variations in production labor costs, with local material and information linkages and costs of product transportation being relatively unimportant (Kale and Lonsdale 1979). Also, smaller communities may have a large number of skilled, nonmilitant workers with a strong work ethic, and they may offer low land costs and low taxes (Hart 1988). Similarly, the location of routine data processing and other "back office" activities often follows a similar pattern, with labor costs being the primary locational determinant. Often the activities or functions at these locations are tied to other corporate locations by means of telecommunications links, through which relevant inputs and outputs are sent and received (Moss and Dunau 1986).

For smaller manufacturing firms, the importance of amenities seems to vary according to the spatial scale at which the location decision is made. Spooner (1973), in a survey of key workers and managers in industrial establishments that had moved into southwestern Great Britain, found amenity factors to be more important in a regional search for a location 
for a new establishment than in a local search. Stafford (1974), in a survey of manufacturing relocation in Ohio, found that firms conducting a regional search placed more emphasis on amenities when choosing a new location for an establishment than did those conducting a local search. For firms conducting a local search, amenities were not as important as traditional factors such as personal contacts, labor factors, transportation, and markets. Amenities specifically installed to attract new establishments were not found to be significant. Smaller business service firms, on the other hand, can usually consider more locations than can manufacturing firms, and, in some cases, they place more emphasis on amenities. Improvements in telecommunications and the growth of contact networking have allowed more of the larger manufacturing and service firms to subcontract services to smaller firms, which allows the larger firms to locate establishments in peripheral areas that may be richer in amenities.

At the local level, amenities become closely intertwined with "hometown" considerations. It is quite common for survey-based studies to find "hometown" as the dominant location factor for small businesses. A survey of more than 800 manufacturing establishments conducted by Urban Systems Research and Engineering, Inc. (1974), for example, showed that locally owned firms usually locate establishments in communities to which the owners have personal attachments. Almost all of the smallest establishments surveyed were located where the company owner lived when the business was started. Surveys of new firms in Pennsylvania and Minnesota indicated that new firms are started by people who live in the area, not by people moving into the area (Reynolds and Freeman 1987; Reynolds and Miller 1987). However, in interviews, many business owners indicated that if their hometown offered a "good quality of life" and were rich in amenity values, they would returm to start businesses. Changes in amenity values may also affect a personal preference for a region or locale in which to conduct business. Although many small businesses, particularly small manufacturers, do not have the resources to conduct a search of alternative locations or access to capital if a suitable alternative location can be identified, it is apparent that smaller producer service firms, particularly those run by highly educated individuals, may respond to changes in the level of amenities and perceived risk in a location.

Structural changes have also been accompanied by significant shifts in the occupational structure of employment, with a larger proportion of the manufacturing labor force now involved in service occupations rather than occupations directly associated with production. As part of this trend, significant growth has occurred in independent business service firms. The separation of activities within many firms and the specialization of functions at each location have led to a spatial division of labor, with different functions supporting specialized occupations at different locations. The cost of attracting and retaining certain occupational groups in a location may be closely related to the level of amenities in a location. Employees in scientific and technical occupations tend to be highly mobile and have been shown to choose locations on the basis of the local or regional provision of amenities. Many firms, therefore, may be indirectly factoring in the effects of amenities in their location decisions, in particular where the development of disamenites may lead to 
migration of essential parts of their labor force away from firm locations. Clearly, the magnitude of the impact of disamenities in a particular existing or potential location is related to the occupational structure of the activity in that location. This is in turn related to a number of factors, in particular the firm's product, technology and employment size.

Researchers have found that for firms locating establishments likely to require a highly educated labor force, decision makers often give careful consideration to the level of amenities (Malecki 1986; Hall et al. 1987). This is the case for high-tech manufacturing, research and development and certain business service activities, including electronic data processing, telecommunications, and consulting services (Malecki and Bradbury 1991). Amenity related factors for these activities also depended on the type of establishment, with favorable housing costs and availability, cultural and recreational facilities, pleasant environment, and social relations with others in the same industry much more significant for branch establishments of multilocation and multinational firms than for single-location establishments (McGregor et al. 1986; Markusen et al. 1986; Hall et al. 1987). Amenities may also be important to the success of office-based firms that need to recruit and maintain staff at new and existing locations. Pacione (1982) considered the effect of residential desirability on interregional office relocation decisions. He found cultural and recreational amenities to be an important part of the decision to choose a new office location. Ley (1985) assessed how amenities affect employee satisfaction at two metropolitan locations, one downtown and one suburban. Cultural and recreational amenities were found to be a more important consideration at the downtown location; environmental amenities were more important at the suburban location.

\section{Research Design}

In this paper, we consider the significance of amenities and disamenities by examining their significance compared to a wide range of other factors known to influence business location decisions. We examine the location preferences of two broad type of business activities, manufacturing and business services, and examine the role of employment size, organizational structure (single establishment firm or establishment of multilocational firm) on how each location factor is rated. Location preferences are examined at two geographic scales, the regional and local, as it known that certain types of business activities that are more flexible in their locational requirements may compare broad regions of the country before comparing specific sites within a region.

Information for the paper was collected through telephone surveys conducted by the West Virginia University Survey Research Center in 1991. Senior executives and other representatives of manufacturing and producer service establishments in the states of Colorado and Utah were surveyed. Colorado and Utah were chosen because (1) both states

have a variety of cultural, recreational, physical and environmental amenities, (2) both states compete with Nevada as sites for firms considering locations for new or expanded establishments, (3) both states have diverse economic bases and are made up of cities and 
communities in a wide range of sizes, (4) data sources on both manufacturing and producer service establishments exist in both states.

A sample of manufacturing establishments were selected from the Colorado and Utah manufacturing directories with an adjustment made to increase the probability that establishments in underrepresented industries would respond. Table 1 shows the industry (SIC) categories of the respondents. The sample of business service establishments was drawn from chamber of commerce listings for locations in Colorado and Utah. The sample was reduced during the survey to include only those business service establishments with sales of more than $50 \%$ to other businesses. Table 2 shows the business services provided by the respondent establishments. The sample is dominated by consulting services ( 87 establishments providing engineering, construction, economic and management consulting services), with computer and telecommunications services, employment services and advertising and market research responding. Details of methodology used and data can be found in Calzonetti and Allison (1992).

To account for the broad differences between manufacturing and business service establishments two questionnaires were used. The surveys covered 27 location factors in six major groups that were (1) important to a firm in evaluating which region of the country in which to locate an establishment and (2) factors important to a firm in comparing two or more localities within a particular region. The factors were in six groups (1) labor (cost and quality), (2) communications, (3) market access, (4) taxes, (5) incentives to new businesses, and (6) amenities (including natural features, cultural and recreational facilities, environmental quality, and other indices of quality of life) (see Table 1). Questions in both surveys collect information about current locational preferences by asking "If you were to choose a location for a new establishment today, how would you rate the importance of (location factor) in evaluating a local (or regional) site?". We therefore measure the level of 'locational stress' associated with existing locations, and those factors most likely to be associated with choosing another, more preferable location.

545 manufacturing establishments and 578 producer service establishments were contacted. 209 manufacturing establishments completed the survey, yielding a response rate of $31.8 \%$. Of these, $179(86 \%)$ were single-location establishments, and $28(13 \%)$ were branch establishments; $125(60 \%)$ had fewer than 20 employees and $82(40 \%)$ had 20 or more employees. More than $71 \%$ of the branch establishments had 20 or more employees; $71.5 \%$ of the single-location establishments had fewer than 20 employees. 214 producer service establishments completed the survey, yielding a response rate of $42.1 \%$. Of these, $128(60 \%)$ were single-location establishments, $48(22 \%)$ were branch establishments of multilocation business service firms, and 31 (14.5\%) were headquarters establishments of multilocation business service firms.

\section{Description of Results}


Tables $1 \mathrm{~A}-1 \mathrm{E}$ and $2 \mathrm{~A}-2 \mathrm{D}$ rank the importance of locational factors according to a rating system based on weighting five response categories by the number of responses in each'. The tables show the five factors receiving the highest ratings in each case, and the rating of all the amenity factors in each case regardless of rating.

Table 1A summarizes the rankings of the local factors for all manufacturing establishments in a local search. As indicated in Table 1A, low business taxes, with an average rating of 3.32 , was rated by manufacturers as the most important factor in a local search. Second to low business taxes is an available building or building site, which scored 3.14. Government attitude toward business was rated third, with an average rating of 3.07. The first amenity factor, quality of education, was rated fourth, with an average rating of 2.97. Following quatity of education were low personal taxes with an average ratings of 2.87. Of the amenity factors, quality of the physical environment was rated seventh, with an average rating of 2.69 , followed by quality of housing (tenth, 2.60), cultural and recreational facilities (twelfth, 2.45), and business and social atmosphere (twentieth, 1.96).

The rankings of factors considered in a local search are differ between single-location establishments and branch establishments (Tables 1B and 1C). Low business taxes, building and building site, and government attitude toward business were the top three factors for both types of establishments. Low business taxes was still rated first by both single-location establishments and branch establishments. Single-location establishments rated the availability of a building or building site as second, whereas this factor was rated third by branch establishments. Again, many single-location establishments simply moved into an available building to start, so the existence of a building was the dominant factor. Government attitude toward business was rated second for the branch establishments. Government incentives was rated fourth for branch establishments and eleventh for singlelocation establishments. This difference is not surprising, since firms opening branch establishments are likely to look for various incentives offered by state and local governments. The quality of education rated fourth for single-location establishments and fifth for branch establishments. Part of the explanation for this result is that the owner of a single-location establishment usually lives in the community in which the establishment is located, so education is viewed as both a business factor and a personal factor for selecting the community. In the case of branch establishments, the purely personal factors are of less value in the selection of a locality, since those in management making the location decision do not necessarily move to the new location.

1 A value of 4 was assigned to and extremely important response, 3 to a very important response, 2 to an important response, 1 to a moderately important response and 0 to an unimportant response. The ratings, or average weights, for each factor were calculated by multiplying responses in each of these categories by the number of respondents, summing across all responses for each factor, and dividing by the total number of responses (see Calzonetti and Allison 1992). 
The distinction between purely personal factors and business factors may also be responsible for single-location establishments ranking low personal taxes (rated fifth) and quality of the physical environment (rated sixth) higher than did the branch establishments. Low personal taxes was rated eleventh for the branch establishments. Quality of the physical environment was ranked sixteenth. Quality of housing was rated tenth for the single-location establishments and ninth for the branch establishments. Cultural and recreational factors were rated twelfth for the single-location establishments and thirteenth for the branch establishments. The comparison between single-location and branch establishments does not offer many surprises with regard to the importance of amenities in business location decisions. Amenity factors were not rated as the top factors by either category of establishments, but quality of the physical environment did rate high for the single-location establishments.

Ratings of location factors are also differ between large (more than 20 employees) (Table 1D) and small establishments (less than 20 employees) (Table 1E). One would expect the smaller single-location establishment to represent an entrepreneurial establishment in which an individual started a business, often in his or her own community. A larger branch establishment would be likely to have been located after an intensive business location search process. Evidence for this hypothesis is that hometown of owner was ranked ninth by smaller single-location establishments and last by larger branch establishments.

Again, low business taxes was the factor ranked highest by both categories. The only other factors rated high by both of these entities were government attitude toward business (which ranked fourth for smaller single-location establishments and second for larger branch establishments) and quality of education (which ranked fifth for smaller single-location establishments and fourth for larger branch establishments). Amenity factors other than quality of education were ranked higher by smaller single-location establishments, whereas traditional economic factors were most important to larger branch establishments. The physical environment was ranked sixth by smaller single-location establishments and seventeenth by larger branch establishments. Cultural and recreational amenities were rated tenth by smaller single-location establishments and thirteenth by larger branch establishments.

Table $2 \mathrm{~A}$ summarizes the rankings of factors considered in a local search by the business service establishments. Amenity-related factors were much more important to producer service establishments than they were to manufacturing establishments, according to the results of this survey. As indicated in Table 14, quality of life was ranked as the top local factor by producer service establishments. Two other amenity factors were listed among the top five factors for the producer service establishments. A safe community was ranked third (behind access to customers), and the quality of the natural environment was ranked fourth. Four other amenity-related factors were ranked among the top 10 local factors: schools (ranked sixth), climate (seventh), housing (eighth), and cultural and recreational facilities (tenth). Factors that were ranked high by manufacturing establishments were not as highly regarded by producer service establishments. For instance, low business taxes was by far the most important local factor to the manufacturing establishment 
respondents, but business taxes was rated eleventh by producer service establishments. Low personal taxes was also not a very important factor to producer service establishments, nor was access to workers, scientists, or engineers.

There were also differences by type of business service establishment for a local search. Table 2B gives the ranking of local factors of importance to the 31 headquarters establishments in the survey. The top factor was quality of life, and two other amenity factors - a safe community and the natural environment - were listed among the top five local factors. Access to customers and low business taxes were listed second and third. Headquarters plants are usually occupied by management, scientific, and technical personnel. The importance of quality of life as the dominant local factor underscores the fact that a desirable location offers advantages in attracting such establishments. Table 1C ranks local factors for the 128 single-location producer service establishments. Single-location establishments were very concerned about amenity factors. Quality of life was most important to them, followed by safe community, natural environment, climate, and schools. The first economic factor, access to customers, was rated sixth. Following access to customers were additional amenity factors. Cultural and recreational facilities was rated seventh, housing cost and quality eighth, and low pollution tenth. Amenity factors are definitely a high priority to small business people when they search for a location. Table ID ranks local factors for the 48 branch establishments of multilocation producer service firms. Amenity factors were less important to branch establishments than single-location establishments. Access to customers and building site were the top two factors to branch establishments. Quality of life was the third-highest-rated factor. Other amenity factors, such as climate, natural environment, and low pollution, did not rank high for the branch establishments.

There were also differences between larger and smaller establishments in the survey of business services. For the larger (those with 20 or more employees) branch establishments of multilocation producer service firms, access to customers ranked high. As shown in Table $1 \mathrm{E}$, access to customers was the most highly rated factor. Schools ranked second for this group of establishments, followed by building site and government attitude toward business.

\section{Summary}

The surveys of manufacturing and producer service establishments in Colorado and Utah indicate that the extent to which business location decisions are related to amenities and disamenities depends closely on product type (manufacturing or business services), type of establishment (single-plant location or branch location for manufacturing activity, singlelocation, branch location, or headquarters location for business service activities), and size of establishment.

Business service establishments ranked amenity factors higher than did manufacturing 
establishments, meaning that business service establishments in potential host locations would seem more likely to be affected by perceptions of risk that might occur with the siting of a nuclear waste facility than would manufacturing establishments. Smaller manufacturing establishments ranked amenity factors higher than larger establishments. For establishments providing business services, quality of life was the highest-ranked factor by both larger and smaller establishments. On the basis of these results, smaller manufacturing establishments and both larger and smaller business service establishments in potential host locations would therefore seem more likely to be affected by any perceptions of risk that might occur with the siting of a nuclear waste facility than would larger manufacturing establishments. For manufacturing establishments, amenity factors were ranked higher by single-location establishments than branch establishments. For establishments providing business services, quality of life was the highest-ranked factor by single-location and headquarters establishments. Single-location manufacturing and business service establishments and headquarters establishments in potential host locations would therefore seem more likely to be affected by any perceptions of risk that might occur with the siting of a nuclear waste facility than would manufacturing and business service branch establishments.

Survey results show that the hometown factor (quality of the natural environment, safe community, climate, schools, cultural and recreational facilities, and housing quality) was found to be important to smaller manufacturing establishments and, in particular, smaller business service establishments. It may be difficult to predict how important any perceptions of risk that might occur with the siting of a nuclear waste facility would be to an entrepreneur operating an establishment in a hometown location. In some situations, the preference for hometown amenities may offset any perceptions of risk that may arise. Whether or not any risk perceptions are offset is likely to depend on the particular amenities offered by each community. It is also likely to depend on the extent to which these amenities are offered by other similar locations at which no nuclear waste facility exists or is planned. Other factors that could also be important in offsetting risk perceptions are (1) the level of access to existing markets and to business contacts that is offered at other locations under consideration and (2) the extent of competition with the firm's product or service there is at other locations being considered.

Amenities also indirectly affect location decisions through the influence they have on the location choices of key technical and scientific personnel. Some establishments require access to high-quality support staff. The quality of local education is an important consideration to individuals choosing an area in which to live and work; it also provides an indication of the quality of support from the higher education system that will be available to a firm. Survey results showed that quality of education was an amenity factor rated among the highest by all categories of manufacturing establishments. The extent to which establishments that rely on a local supply of key technical and support staff and a high-quality local education system would be affected by perceptions of risk that might occur with the siting of a nuclear waste facility would depend on two factors: (1) how any perceptions of risk held by key personnel in the establishments to be located in potential host locations would influence their location preferences and (2) how any perceptions of risk held 
by those involved in the higher education system would affect the evaluation of present locations.

\section{Discussion}

The findings of the surveys of business establishments in Colorado and Utah can provide some insight to the assessment of the magnitude of the economic impacts of HLNW facilities. While amenity factors are important for a range of business activities, other key nonamenity factors in an area must also be favorable before a firm is likely to choose a location there for a new or expanded business establishment. The likely impact of a HLNW facility on potential nēw and existing business activity in any given location is closely dependent on the economic characteristics of each potential location in addition to the level of amenities it offers. It is likely therefore that many of the locations that are chosen or that might volunteer to become sites for HLNW facilities are not able to offer many of the favorable locational characteristics to attract many types of business activities. It may be possible therefore to predict the likelihood of certain types of business activities locating in particular areas by combining the findings of the two surveys with information on the economies of potential host sites, in particular, the Las Vegas region (the potential host for the permanent nuclear waste repository at Yucca Mountain) and rural areas likely to volunteer to host temporary nuclear waste storage (MRS) facilities.

The importance of amenity and nonamenity factors with respect to the location of existing and potential new business activities is likely to be very different in the Las Vegas area than it is in rural areas, as is the impact of any risk perceptions associated with nuclear waste facilities. These differences relate not only to the type of amenities available (those offered by Las Vegas compared with those offered by rural locations) but also to the characteristics of the local economy (Las Vegas versus rural locations) and the influence they have on which business activities are likely to locate in either area.

Thr growth and on-going diversification of the economy of the Las Vegas metropolitan area away from gaming and hospitality industries means that the area now supports, and can attract, a much wider range of business activities. Changes in the level of amenities or any perceptions of risk that might develop in the Las Vegas area as a result of the repository program therefore have the potential to affect a wide range of business activities. Survey results show that amenities are often very important to headquarters establishments and establishments involved in other business activities requiring high-order executive and white-collar personnel (e.g., finance, insurance, legal, services, advertising, and research and development activities). Establishments involved in these activities are usually drawn to the type of amenities found in larger metropolitan areas, such as those now developing in the Las Vegas area. Other factors important to headquarters facilities (e.g., the need to minimize costs associated with face-to-face contacts between employees and clients, customers, or other key personnel in the firm) have also recently begun to favor locations other than the traditional ones of New York, Chicago, Los Angeles, and San 
Francisco.

Smaller firms that market specialized business services also often locate establishments in larger urban areas, in order to be close to headquarters establishments of other firms and to the types of amenities that might attract new headquarters establishments. These smaller firms might consider locating in the Las Vegas area, and they might also be affected by changes in the level of amenities Las Vegas offers. In particular, some of these smaller specialized producer service firms (e.g., those that provide consulting services in engineering, management, or computing or offer architectural, marketing, or financial services) might be able to compete from locations in the Las Vegas area, because of general improvements in conventional mail services and in particular the recent improvements in local telecommunications-developed for the entertainment sector, coupled with these firms' increased use of contact networks to gain access to and maintain customers located in larger metropolitan areas.

Las Vegas's environmental amenities, particularly its recreational amenities, and its lack of the disamenities often associated with larger urban centers might be attractive to firms if it is clear that the area has or can attract key scientific and technical personnel from elsewhere. In these cases, the amenities offered by the Las Vegas area might indirectly influence the decision of some firms with respect to locating particular types of business establishments. For example, the quality of education influenced the location decisions of many of the manufacturing establishments in Colorado and Utah. In addition, Las Vegas's amenities might influence the location decisions being made by smaller business service establishments and specialized manufacturing establishments, which might be started in Las Vegas by people previously employed by larger firms located elsewhere.

Although survey results show that cultural and environmental amenities are much more likely to influence the location of business service activities than manufacturing activities, amenities may still indirectly influence the location decisions of larger manufacturing firms that are deciding where to locate branch establishments that manufacture products in their early stages of development. These types of manufacturing branch establishments need to be close to headquarters and research and development establishments that provide initial support. Las Vegas has been successful in attracting a small number of manufacturing branch establishments that engage in activities of this type. Thus, changes in the level of amenities offered by Las Vegas could indirectly and adversely affect the location decisions being made for these establishments, because of the importance of amenities to headquarters and research and development establishments.

Routine manufacturing production not requiring substantial scientific and technical backup can be undertaken by branch establishments, for which the cost and availability of production labor are the prime location factors. Las Vegas's lower cost of doing business compared with its main competitor, the Los Angeles area, and its proximity to markets in southern California and southern Arizona may draw branch establishments to the area in the near future. Survey results show that amenity factors are much less likely to be important to 
manufacturing branch establishments engaged in routine production activities, primarily because these establishments have few positions for executive, scientific, and technical staff. The same factors that are important for locating routine production functions are also important for locating routine office functions in both manufacturing firms and producer service firms. Branch establishments of manufacturing and business service firms that have been attracted to the Las Vegas area are unlikely to be affected by any risk perceptions associated with the Yucca Mountain project.

Although smaller single-location establishments are not as important as larger multilocation firms in terms of total employment, they do dominate the Las Vegas economy in terms of their absolute number. Smaller single-location establishment firms are also likely to be an important part of the economies of small rural communities, which are the locations likely to host temporary nuclear waste (MRS) facilities. Survey results indicate that changes in amenities and any risk perceptions that arise as a result of the siting of a nuclear waste facility are likely to be important to smaller manufacturing and producer service firms, primarily because the individual preferences of the entrepreneur (particularly knowledge of local markets and suppliers and preference for hometown locations) are often the most important factor in the location decision of smaller firms. For these firms, in particular, local cultural amenities may provide a basis for a location decision and may be a more important factor than amenities in the natural environment.

The Las Vegas economy has developed the potential to attract a range of business activities on the basis of its various amenity and nonamenity factors. The rural nature of locations likely to volunteer to host MRS facilities, however, limits the range of business activities likely to locate in these communities. Smaller single-location manufacturing and producer service establishments are likely to continue to be the main establishments found in these communities. As has been suggested, hometown factors are often important when a change in the level of amenities or any perceptions of risk that may arise with the siting of a nuclear waste facility may influence the decision to remain in a small community or choose another location in a similar community elsewhere. Market considerations, such as access to labor markets, the extent of the firm's contact network and the level of product competition in possible alternate locations, are also important and may not favor a move to another location for many smaller single-location firms.

Larger firms might also locate establishments engaged in manufacturing or routine office functions in rural areas. Survey results show that amenities are not usually considered in decisions on where to locate these types of establishments. The location choice for establishments engaged in these activities is also unlikely to be affected by any risk perceptions that arise from the siting of a nuclear waste facility. Even though amenities are important to the people who choose locations for manufacturing or producer service branch establishments, these decision makers do not themselves work in the rural areas but rather in corporate headquarters in larger metropolitan areas. It is unlikely that any perceptions of risk that develop in the community in which branch facilities are located would affect a choice of whether to continue to do business or locate a new establishment in a community 
hosting a nuclear waste facility.

The surveys of manufacturing and business service establishments in Colorado and Utah show that amenities are a significant factor considered in their evaluations of a location as a place to do business. This finding suggests that undesirable changes in the quality of amenities and the development of any perceived risk that might result from the siting of a nuclear waste facility would have predictable effects on business location behavior. These undesirable changes and perceptions would probably degrade an area's image as an attractive business location and possibly hinder future business development opportunities in that area. As has been suggested in the case of Las Vegas and for smaller rural communities, however, the actual impact of any perceived risk that may arise as a result of siting a nuclear waste facility on business tocation decisions is likely to vary considerably, depending on (1) the economic characteristics of the location under consideration, and therefore the type of business and business activity that is or might be attracted to that location, and (2) the importance of amenities to each type of business activity, and therefore each business's sensitivity to any perceived risk that might develop as a result of the siting of a nuclear waste facility. These factors must be considered in any estimations of the likely impacts from siting a nuclear waste facility on business location decisions and in any attempts to mitigate or compensate for these impacts in communities and regions that might become hosts to a nuclear waste facility.

\section{Acknowledgements}

The research reported in this paper was partially supported by the U.S. Department of Energy, Office of Civilian Radioactive Waste Management, under contract W-31-109-Eng38. The authors would like to thank William B. Beyers, Edward J. Malecki and Howard A. Stafford for their comments and suggestions on the survey instrument, and the West Virginia University Survey Research Center for administering the telephone survey. The findings, comments and recommendations found in this paper, however, are those of the authors and are not necessarily those of the U.S. Department of Energy.

\section{References}

Allison, T., 1991, Socioeconomic Assessment Guidance Report: Determining the Effects of Amenity Characteristics on Business Location Decisions, ANL/EAIS/TM-85, Argonne National Laboratory, Argonne, IL., Feb.

Ballard, S.C., and T.E. James (editors), 1983, The Future of the Sunbelt, Praeger, New York, NY.

Bassett, G., and R. Hemphill, 1991, "Comments on "Perceived Risk Stigma, and Potential Economic Impacts of a High-Level Nuclear Waste Repository in Nevada" "Risk Analysis 
11:697-700.

Burgess, J.A., 1982, "Selling Places: Environmental Images for the Executive," Regional Studies 16:1-17.

Burns, L., and W.N. Pang, 1977, "Big Business in the Big City: Corporate Headquarters and the CBD," Urban Affairs Quarterly 12:533-544.

Calzonetti, F.J., and T. Allison, 1992, An Empirical Investigation of the Importance of Amenities and Other Factors on Business Location Decisions, ANL/EAIS/TM-92, Argonne National Laboratory, Argonne, IL., November.

Calzonetti, F.J., and R.C. Hemphill, 1990, Assesing the Impacts of Regional Characteristics on the Location of Manufacturing Facilities: A Review of Recent Methods and Findings ANL/EAIS/TM-64, Argonne National Laboratory, Argonne, IL., November.

Carlino, G., and E. Mills, 1987, "The Determinants of County Growth" Journal of Regional Science 27:39-54.

Center for Survey Research, 1988, National Telephone Survey of Nuclear Waste Issues Report prepared for the Nevada Agency for Nuclear Projects/ Nuclear Waste Project Office, Carson City, NV.

Crown, W., 1991, "Migration and Regional Economic Growth: An Origin-Destination Model" Economic Development Quarterly 5:45-59.

Decision Research and Mountain West Research, 1989, What comes to Mind When You Hear the Words "Nuclear Waste Repository"? A Study of 10,000 Images Report prepared for the Nevada Agency for Nuclear Projects/ Nuclear Waste Project Office, Carson City, NV.

Decision Research and Mountain West Research, 1990, Perceived Risk, Stigma and the Potential Economic Impacts of a High-Level Nuclear Waste Respository in Nevada Report prepared for the Nevada Agency for Nuclear Projects/ Nuclear Waste Project Office, Carson City, NV.

Easterling, D. and H. Kunreuther, 1990, The Vulnerability of the Convention Industry to the Siting of a High-Level Nuclear Waste Repository Report prepared for the Nevada Agency for Nuclear Projects/ Nuclear Waste Project Office, Carson City, NV.

Erikson, K., 1994, "Out of Sight, Out of Our Minds" New York Times Magazine, pp3441,50. March 6.

Fox, W., et al., 1985, An Economic Analysis of a Monitred Retreivable Storage Site for Tennessee Report prepared by the Center for Business and Economic Research, University of 
Tennessee, Knoxville, TN.

Gottlieb, P., 1994, "Amenities as an Economic Development Tool: Is There Enough Evidence?" Economic Development Quarterly 8:270-285.

Greenhut, M.L., 1956, Plant Location in Theory and Practice, University of North Carolina Press, Chapel Hill, NC.

Greenwood, M., 1981, Migration and Economic Growth in the United States New York, Academic Press.

Growth Strategies Organization, 1988a, Current Target Industry Analysis: Las Vegas Metropolitan Area Report prepared for the Nevada Agency for Nuclear Projects/ Nuclear Waste Project Office, Carson City, NV.

Growth Strategies Organization, 1988b, Business Profile of Metropolitan Las Vegas Report prepared for the Nevada Agency for Nuclear Projects/ Nuclear Waste Project Office, Carson City, NV.

Hall, P., et al., 1987, Western Sunrise: The Genesis and Growth of Britain's Major HighTech Corridor, Allen Unwin, Boston, MA.

Haider, D., 1992, "Place Wars: New Realities in the 1990s," Economic Devlopment Quarterly 6:127-134.

Hart, J.F., 1988, "Small Towns and Manufacturing," The Geographical Review 78:272-287.

Ihlanfeldt, K., and M. Raper, 1990, "The Intrametropolitan Location of New Office Firms," Land Economics 66:182-198.

Kale, S.R., and R.E. Lonsdale, 1979, "Factors Encouraging and Discouraging the Location of Industries in Non-Metropolitan Areas, " in Non-Metropolitan Industrialization, R.E.

Lonsdale and H.L. Seyler (editors), John Wiley \& Sons, Inc., New York, NY.

Kasarda, J., and M. Irwin, 1991, "National Business Cycles and Community Competiton for Jobs" Social Forces 69:733-61.

Keeble, D.E., 1980, "Industrial Decline, Regional Policy and the Urban-Rural Manufacturing Shift in the U.K.," Environment and Planning A 12:954-962.

Keeble, D.E., 1989, "High-Technology Industry and Regional Development in Britain: The Case of the Cambridge Phenomenon," Environment and Planning C 7:153-172.

Kunreuther, H., et al., 1988, Nevada's Predicament: Public Perceptions of Risk from the 
Proposed Nuclear Waste Repository Environment 30:17-20, 30-33.

Kunreuther, H., et al., 1988, The Convention Planning Process: Potential Impacts of a Repository in Nevada Report prepared for the Nevada Agency for Nuclear Projects/ Nuclear Waste Project Office, Carson City, NV.

Ley, D., 1985, "Downtown or the Suburbs? A Comparative Study of Two Vancouver Head Offices," The Canadian Geographer 29:30-43.

Malecki, E., 1986, "Research and Development and the Geography of High-Tech Complexes" in Technology, Regions and Policy ed. Rees, J., Rowan and Littlefield, Totowa, NJ.

Malecki, E., 1989, "What about People in High Technology? Some Research and Policy Considerations," Growth and Change 20:67-79.

Malecki, E., and S. Bradbury, 1991, "R\&D Facilities and Professional Labor: Labor Force Dynamics in High-Technology" Regional Studies 26:123-36.

Markusen, A., et al., 1986, High-Tech America, Allen Unwin, Boston, MA.

McGregor, B.D. et al., 1986, "The Development of High Technology in the Newbury District," Regional Studies 20:433-448.

McNulty, R., 1986, "Pollyanna, or Is the Glass Half Full?" Annals of the American Academy of Political and Social Science 488:148-156.

Moss, M., and A. Dunau, 1986, The Location of Back Offices: Emerging Trends and Development Patterns, New York University, Real Estate Institute, New York, NY.

Mushkatel et al. 1990, Risk-Induced Social Impacts: The Effects of the Proposed Nuclear Waste Repository on the Residents of the Las Vegas Metropolitan Area Report prepared for the Nevada Agency for Nuclear Projects/ Nuclear Waste Project Office, Carson City, NV.

Myers, D., 1987, "Internal Monitoring of Quality of Life for Economic Development," Economic Development Quarterly 1: 268-278.

Pacione, M., 1982, "Space Preferences, Locational Decisions, and the Dispersal of Civil Servants from London," Environment and Planning A 14:323-333.

Raitz, K., 1988, "Advantages of Place as Perceived by Sunbelt Promoters," Growth and Change 19:14-29.

Reynolds, P., and S. Freeman, 1987, 1986 Pennsylvania New Firm Survey, Appalachian 
Regional Commission, Washington, DC.

Reynolds, P., and B. Miller, 1987, 1987 Minnesota New Firm Survey, University of Minnesota, Hubert Humphrey Center, Minneapolis, MN.

Rhodes, J., and A. Kan, 1971, Office Dispersal and Regional Policy, Cambridge University Press, Cambridge, Great Britain.

Schmenner, R.W., 1982, Making Business Location Decisions, Prentice Hall, Inc., Englewood Cliffs, NJ.

Slovic, P., et al. 1989, Perceived Risk, Stigma, and Potential Economic Impacts of a HighLevel Nuclear Waste Respository in Nevada Report prepared for the Nevada Agency for Nuclear Projects/ Nuclear Waste Project Office, Carson City, NV.

Slovic, P., et al. 1991, "Perceived Risk, Stigma, and Potential Economic Impacts of a HighLevel Nuclear Waste Repository in Nevada" "Risk Analysis 11:683-696.

Smith, D., 1971, Industrial Location, John Wiley \& Sons, Inc., New York, NY.

Spooner, D., 1973, "Industrial Movement and the Rural Periphery: The Case of Devon and Cornwall," Regional Studies 6:197-215.

Stafford, H., 1974, "The Anatomy of the Location Decision: Content Analysis of Case Studies," in Spatial Perspectives on Industrial Organization and Decisionmaking, F.E.I. Hamilton (editor), John Wiley \& Sons, Inc., New York, NY.

Steinnes, D., 1982, "Do People Follow Jobs or Do Jobs Follow People?" Urban Studies 19:187-92.

Urban Systems Research and Engineering, Inc., 1974, Small City Manufacturing Growth, U.S. Department of Health, Education and Welfare, Washington, DC.

Wheat, L.F., 1986, "The Determinants of 1963-77 Regional Manufacturing Growth: Why the South and West Grow," Journal of Regional Science 26:635-658. 
Table 1. Business Location Factors Used in Surveys of Manufacturing and Business Service Establishments

Importance of Cost and Ouality of:

Scientific and Technical Staff

Administrators and Managers

Clerical Staff

Production Workers

Skilled and Supervisory Production Staff

Telecommunications Services

Local Business Services

Public Utilities

Importance of Access to:

Customers

Other Facilities of Own Company

Suppliers

Natural Resources

Interstate Highways

Air Service

Rail and Water Transportation

Research and Development (Government and Private)*

Universities*

Government Departments*

Importance of:

Low Personal Taxes

Low Business Taxes

Government Incentives to Attract Industry

Community and State Attitudes Toward Business

Non-Union Labor or Right-to-Work Law

Importance of:

Quality of Housing

Physical Environment

Quality of Education

Cultural and Recreational Facilities

Social Interaction with others in Similar Business

Hometown of Owner or Manager

Cost and Availability of Suitable Building/Building Site

Quality-of-Life*

Climate (Temperature, Weather)*

Clean Air, Lack of Congestion and Crime*

*The importance of these factors were only examined in the survey of business service establishments. 
Table 2. Rating of Factors Considered by Manufacturing Establishments, by Size and Type of Establishment (27 Total Factors)

RANK FACTOR

A. All Establishments

1. Low Business Taxes

2. Building $\backslash$ Building Site Cost and Availability

3. Community and State Attitude to Business

4. Quality of Education

5. Low Personal Taxes

7. Physical Environment

10. Quality of Housing

12. Cultural/Recreational Facilities

15. Hometown of Owner

21. Business and Social Atmosphere

B. Single-Location Establishments

1. Low Business Taxes

2. Building(Building Site Cost and Availability

3. Community and State Attitude to Business

4. Quality of Education

5. Low Personal Taxes

6. Physical Environment

9. Hometown of Owner

10. Quality of Housing

12. Cultural/Recreational Facilities

21. Business and Social Atmosphere

C. Branch Establishments

1. Low Business Taxes

2. Community and State Attitude to Business

3. Building $\backslash$ Building Site Cost and Availability

4. Government Incentives

5. Quality of Education

9. Quality of Housing

13. Cultural/Recreational Facilities

16. Physical Environment

20. Business and Social Atmosphere
RATING

3.07

2.97

2.87

2.69

2.60

2.45

2.30

1.96

3.34

3.18

3.04

3.01

2.99

2.81

2.59

2.58

2.44

1.91

3.39

3.18

3.04

3.00

2.89

2.75

2.61

2.36

2.04 
D. Single-Location Establishments with Less Than 20 Employees

1. Low Business Taxes

3.41

2. Building/Building Site Cost and Availability

3.17

3. Low Personal Taxes

3.11

4. Government Business Attitude 3.07

5. Quality of Education 2.99

6. Physical Environment 2.82

8. Quality of Housing 2.57

10. Cultural/Recreational Facilities 2.47

18. Business and Socíal Atmosphere 1.96

E. Branch Establishments with More Than 20 Employees

1. Building/Building Site Cost and Availability 3.20

2. Low Business Taxes $\quad 3.16$

3. Quality of Education 3.07

4. Nonunion Labor 3.04

5. Government Business Attitude 2.98

7. Physical Environment 2.78

11. Quality of Housing 2.68

15. Cultural/Recreational Facilities $\quad 2.36$

24. Business and Social Atmosphere 1.78 
Table 3. Rating of Factors Considered by Business Service Establishments, by Size and Type of Establishment (34 Total Factors)

RANK FACTOR

A. All Establishments

1. Quality of Life

2. Customers

3. Safe Community

4. Natural Environment

5. Building Site $=$ -

6. Quality of Education

7. Climate

8. Housing Cost and Quality

10. Cultural/Recreational Facilities

12. Clean Air, Lack of Congestion and Crime

22. Business and Social Atmosphere

B. Multilocation Headquarters Establishments

1. Quality of Life

2. Customers

3. Low Business Taxes

4. Clean Air, Lack of Congestion and Crime

5. Natural Environment

8. Climate

9. Housing Cost and Quality

12. Clean Air, Lack of Congestion and Crime

13. Quality of Education

14. Cultural/Recreational Facilities

25. Business and Social Atmosphere

\section{Single-Location Establishments}

1. Quality of Life

2. Clean Air, Lack of Congestion and Crime

3. Natural Environment

4. Climate

5. Quality of Education

7. Cultural/Recreational Facilities

8. Housing Cost and Quality

10. Clean Air

21. Business and Social Atmosphere
RATING

3.38

3.11

3.09

2.98

2.95

2.90

2.90

2.84

2.79

2.73

2.03

3.26

3.10

3.06

2.90

2.87

2.77

2.74

2.65

2.61

2.58

1.84

3.58

3.31

3.25

3.13

2.98

2.95

2.93

2.89

2.06 
D. Branch Establishments

1. Customers 3.58

2. Building Site $\quad 3.10$

3. Quality of Life 3.00

4. Convince to Business $\quad 2.92$

5. Quality of Education 2.92

7. Housing Cost and Quality 2.77

9. Cultural/Recreational Facilities 2.63

12. Climate - - 2.54

13. Natural Environment 2.50

14. Clean Air, Lack of Congestion 2.44

21. Business and Social Atmosphere 2.17

E. Branch Establishments with More Than 20 Employees

1. Customers 3.76

2. Quality of Education 3.05

3. Building Site 3.05

4. Government Attitudes 2.95

5. Quality of Life 2.90

6. Housing Cost and Quality $\quad 2.86$

11. Cultural/Recreational Facilities 2.48

12. Climate 2.43

13. Clean Air, Lack of Congestion $\quad 2.43$

17. Business and Social Atmosphere $\quad 2.29$

21. Natural Environment $\quad 2.19$ 